\title{
Quality characteristics of Pueraria thunbergiana extracts depending on drying methods
}

\author{
Yu-Ri Kwon ${ }^{1,2}$, San Nam ${ }^{1}$, Da Som Jeong ${ }^{1}$, Ri Eun Kwon ${ }^{1}$, Kwang-Sup Youn ${ }^{1,2 *}$ \\ ${ }^{1}$ Department of Food Science and Technology, Catholic University of Daegu, Gyeongsan 38430, Korea \\ ${ }^{2}$ Institute of Food Science and Technology, Catholic University of Daegu, Gyeongsan 38430, Korea
}

\section{건조방법에 따른 칡 추출물의 품질특성}

\author{
권유리 ${ }^{1,2} \cdot$ 남산 $^{1} \cdot$ 정다솜 $^{1} \cdot$ 권리은 $^{1} \cdot$ 윤광섭 $^{1,2 *}$ \\ ${ }^{1}$ 대구가톨릭대학교 식품공학전공, ${ }^{2}$ 대구가톨릭대학교 식품과학연구소
}

\begin{abstract}
This study was designed to compare the quality characteristics of spray-dried (SD) and freeze-dried (FD) Pueraria thunbergiana extracts powder hot water extracts. Quality characteristics of the SD and FD powder including moisture content, color value, water absorption index, water solubility index, dynamic angle and antioxidant activities were evaluated. The moisture content of SD powder $(1.50 \%)$ was lower than that of FD powder $(2.92 \%)$. $L^{*}$ and $b^{*}$ values of SD powder was lower than of FD powder. The water absorption index was higher in FD powder (1.40) and water solubility index in SD powder $(\mathbf{9 4 . 1 0 \%})$ was higher than that FD powder $(90.69 \%)$. Dynamic angle of SD powder $\left(36.46^{\circ}\right)$ was higher than that of FD powder $\left(33.30^{\circ}\right)$. The DPPH radical scavenging activities of $5 \mathrm{mg} / \mathrm{mL}$ solution of SD powder and FD powder were $85.38 \mathrm{mg} / \mathrm{mL}, 59.38 \mathrm{mg} / \mathrm{mL}$, respectively. And, the same trend was observed for the ABTS radical scavenging activities of the drying powder as that observed for their DPPH radical scavenging activities. There were relatively higher contents of phenolic compounds in SD powders than in FD powders. In conclusion, spray-dried Pueraria thunbergiana extracts showed the high WSI, polyphenol, DPPH and ABTS radical scavenging activities and low moisture content and dynamic angle than freeze dried powder.
\end{abstract}

Key words : Pueraria thunbergiana, quality characteristics, drying method, spray drying, freeze drying

\section{서 론}

칡(Pueraria thunbergiana)은 콩과에 속하는 다년생 덩굴 성 관목으로 우리나라를 비롯하여 동남아시아 각지에서 자생하는 두과(Leguminosae) 식물이며 한국, 일본, 중국 등 에서 산과 들에 자생하고 있다(1). 뿌리는 약 16 19\%가 전분으로 구성되어 있으며(2), 생리활성 물질인 isoflavone, oligosaccharide, peptide, phytate, 식이섬유, 식물성 sterols, phenol 성분, saponin 등을 함유하고 있어 기능성 식품으로

*Corresponding author. E-mail : ksyoun@cu.ac.kr Phone : 82-53-850-3209, Fax : 82-53-850-3209

Received 6 July 2016; Revised 16 August 2016; Accepted 29 August 2016.

Copyright (c) The Korean Society of Food Preservation. All rights reserved.
서 주목을 받고 있다(3-5). 옛부터 약재로 쓰이던 칡은 발한, 해열제, 감기, 고혈압, 협심증, 당뇨병, 숙취 제거 등에 효과 적인 것으로 알려져 있다(6). 또한 많은 연구를 통해 칡의 polyphenol류인 catechin 성분이 항산화 효과 외에 해열, 해 독 등 간장병과 관련한 약리작용에 관한 효능평가가 이루어 지고 있으며, 지질의 과산화물 생성을 방제하는 효과나 생 체에 대해 지질막 등의 보호작용, 골다공증 치료 효과 등이 보고되고 있다(7).

칡의 다양한 기능성과 약리 작용에도 불구하고 계절적 한계성과 짧은 저장기간, 갈변 등의 원인으로 원료 그대로 관리하는 것이 어려워 칡의 사용이 제한적이다. 따라서, 이를 보완하기 위해 칡은 절단하여 건조한 갈근이나 칡 추출물을 첨가한 건강기능성 식품 및 가공 식품이 개발되어 시판되고 있으며, 칡 국수(8), 칡 설기(9), 칡 묵(10), 칡 전분 을 첨가한 라면(11), 칡 분말을 이용한 기능성 빵(12) 등을 
가공식품에 적용하기 위한 연구가 다수 진행되고 있다. 그 러나 추출물의 건조공정에 따른 품질특성에 관한 연구는 거의 없어 건조분말의 제조 공정 개선과 품질향상에 관한 연구가 필요한 실정이다.

액상식품을 분말화 하는 대표적인 방법으로는 열풍건조, 분무건조, 동결건조, 진공건조 등이 있으며, 이 중 분무건조 와 동결건조는 식품 산업에서 주로 사용하는 건조법이다. 분무건조는 추출액 또는 농축액을 미세한 액적 형태로 열풍 내에 분무하여 단시간에 건조하는 방법으로 건조비용이 저렴하고 건조시간이 짧으며 구형의 입자로 용해성, 분산 성이 좋아 인스턴트 분말 제조에 적합하며, 연속적으로 대 량 처리가 가능하여 산업현장에서 보편적으로 사용할 수 있는 장점이 있다(13). 동결건조는 식품 내 물을 얼음으로 바꾼 후 고체 상태를 유지하며 승화 건조하는 방법으로, 열 손상 같은 품질의 저하를 막을 수 있어 제품의 복원성과 품질이 가장 우수하다는 장점이 있다 $(14,15)$.

따라서 본 연구에서는 다양한 생리활성을 가지고 있는 칡 추출물을 동결 및 분무 건조하여 칡 분말을 제조하고 품질특성을 비교 분석함으로써 칡 분말의 식품 소재화에 대한 기초자료를 제시하고자 하였다.

\section{재료 및 방법}

\section{재 료}

본 실험에서 사용된 칡은 강원도 정선에서 2014년 12월 채취한 생 칡을 구매하여 사용하였으며, 흙과 먼지 등의 이물질을 제거하여 $5 \sim 10 \mathrm{~cm}$ 길이로 절단한 후 $4^{\circ} \mathrm{C}$ 에서 보관 하면서 사용하였다.

\section{추출물의 제조 및 건조}

칡 추출물의 제조는 절단한 칡 $2.5 \mathrm{~kg}$ 에 6배의 증류수를 가하여 압력 한약추출기(Finepack. Co., Korea)를 사용해 $105^{\circ} \mathrm{C}$ 에서 6시간 추출하였다. 추출액은 여과지에 걸러 불 순물을 제거한 뒤 회전 감압농축기 $(\mathrm{N}-\mathrm{N}$ series, Eyela, Tokyo, Japan)를 이용해 $70^{\circ} \mathrm{C}$ 에서 최종 농도가 $30{ }^{\circ} \mathrm{Brix}$ 가 될 때까지 감압 농축한 다음 동결건조기(FDSFDSM12, Samwon, Seoul, Korea)와 분무건조기(KL-8, Seogang Engineering Co., Ltd., Cheonan, Korea)를 이용하여 분말 시료를 제조하였으며 $-70^{\circ} \mathrm{C}$ 에 보관하면서 실험에 사용하였 다. 분무건조 조건은 heating condition $185^{\circ} \mathrm{C}$, pump speed $10 \%$, flow control 400 600, aspirator $70 \%$ 이었다.

\section{수분 및 색도}

수분함량은 적외선 수분측정기(IRD-250, Woori Sci. Co. Pocheon, Korea)를 사용하여 측정하였으며, 색도는 색차계 (CR-200 Minolta, Tokyo, Japan)로 측정하였으며, 밝기를
나타내는 $\mathrm{L}^{*}$ (lightness), 적색도를 나타내는 $\mathrm{a}^{*}$ (redness), 황 색도를 나타내는 $\mathrm{b}^{*}$ (yellowness) 및 $\mathrm{H}^{\circ}$ (hue angle value)를 측정하였다.

수분흡수지수(WAI) 및 수분용해지수(WSI) 측정

수분흡수지수(water absorption index, WAI) 및 수분용해 지수(water solubility index, WSI) 측정은 Phillips 등(16)의 방법을 변형하여 측정하였다. 건조분말 $0.5 \mathrm{~g}$ 에 $20 \mathrm{~mL}$ 증류 수를 첨가하여 $3,000 \mathrm{rpm}$ 에서 20분간 원심분리한 후 침전물 은 수분흡수지수로 계산하였으며, 상등액은 미리 무게를 구한 수기에 분리하여 $105^{\circ} \mathrm{C}$ 에서 4 시간 동안 건조시킨 고형 분을 수분용해지수로 사용하여 아래와 같이 계산하였다.

$$
\begin{gathered}
\text { 수분흡수지수 }(\mathrm{WAI})=\frac{\text { 침전물의 양 }}{\text { 시료의 양 }} \\
\text { 수분용해지수(WSI, \%) }=\frac{\text { 상등액 고형분의 양 }}{\text { 시료의 양 }} \times 100
\end{gathered}
$$

안식각

안식각은 시료의 free-flowingness를 알아 볼 수 있는 쌓임 각의 방법(17)을 변형하여 측정하였다. 시료 $20 \mathrm{~g}$ 을 고정시 킨 깔때기에 넣고 일시에 내려오도록 진동시켰다. 평면 위 로 낙하되어 건조분말이 원뿔모양으로 퇴적시킨 후 원주의 모선을 그리고 20 군데를 지정하여 평균 반지름을 측정하 였고, 깔때기와 수평면과의 높이를 측정하여 수평면과 이 루는 각을 측정하였으며 다음 식을 이용하여 안식각을 계산 하였다.

Angle of repose $(\cot a)=r($ 원주의 반지름 $) / h($ 깔때기와 수평 면이 이루는 높이)

\section{총 폴리페놀 함량 측정}

Dewanto 등(18)의 방법에 따라 추출물 $100 \mu \mathrm{L}$ 에 $2 \%$ sodium carbonate $2 \mathrm{~mL}$ 과 $50 \%$ Folin-Ciacalteu reagent 100 $\mu \mathrm{L}$ 을 가한 후 $720 \mathrm{~nm}$ 에서 흡광도를 측정하였으며 gallic $\operatorname{acid}($ Sigma-Aldrich Co., USA)의 검량선에 의하여 함량을 산출하였다.

\section{총 플라보노이드 함량 측정}

Abdel-Hameed(19)의 방법에 따라 추출물 $100 \mathrm{~mL}$ 에 $5 \%$ sodium nitrite $0.15 \mathrm{~mL}$ 을 가한 후 $25^{\circ} \mathrm{C}$ 에서 6 분간 방치한 다음 $10 \%$ aluminium choloride $0.3 \mathrm{~mL}$ 를 가하여 $25^{\circ} \mathrm{C}$ 에서 5 분간 방치하였다. 다음 $1 \mathrm{~N} \mathrm{NaOH} 1 \mathrm{~mL}$ 를 가하고 vortex상 에서 가한 후 $510 \mathrm{~nm}$ 에서 흡광도를 측정하였으며 rutin hydrate(Sigma-Aldrich Co., USA)의 검량선에 의하여 함량 을 산출하였다. 


\section{$\mathrm{DPPH}$ radical 소거활성 측정}

Blois(20)의 방법에 따라 시액 $0.2 \mathrm{~mL}$ 에 $0.4 \mathrm{mM} \mathrm{DPPH}$ (1,1diphenyl-2-picryl-hydrazyl)용액 $0.8 \mathrm{~mL}$ 를 가하여 10 분 간 방치 한 다음 $525 \mathrm{~nm}$ 에서 흡광도를 측정하였으며 계산 식, electron donating ability $(\%)=100-[(\mathrm{OD}$ of sample/OD of control $\times 100]$ 에 의하여 활성도를 산출하였다.

\section{ABTS radical 소거활성 측정}

$\mathrm{Re}$ 등(21)의 방법에 따라 $7.4 \mathrm{mM} \mathrm{ABTS}[2,2$ '-azino-bis(3ethylbenzothiazoline-6-sulfonic acid) diammonium salt]와 $2.6 \mathrm{mM}$ potassium persulfate를 혼합하여 실온 - 암소에서 24시간 동안 방치하여 radical을 형성시킨 다음 실험 직전에 $\mathrm{ABTS}$ 용액을 $732 \mathrm{~nm}$ 에서 흡광도가 $0.700 \pm 0.030$ 이 되도록 phosphate buffer saline(PBS, pH 7.4)로 희석하여 사용하였 다. 희석된 용액 $950 \mu \mathrm{L}$ 에 추출물 $50 \mu \mathrm{L}$ 를 가하여 암소에서 10 분간 방응시킨 후 $732 \mathrm{~nm}$ 에서 흡광도를 측정하였으며 계산식, ABTS radical scavenging ability $(\%)=100-[(\mathrm{OD}$ of sample/OD of control) $\times 100$ ]에 의하여 활성을 산출하였다.

\section{통계처리}

모든 실험은 3회 반복으로 행하여 평균치와 표준편차로 나타내었고, 유의성 검증은 SPSS 12(SPSS Inc., Chicago, $\mathrm{IL}, \mathrm{USA}$ ) software package program을 이용하여 t-test를 행 하였다.

\section{결과 및 고찰}

수분 함량 및 색도

칡 추출물의 분무건조 및 동결건조 분말의 수분 함량 및 색도를 비교한 결과는 Table 1 과 같다. 수분 함량의 경우 분무건조가 $1.50 \%$, 동결건조가 $2.92 \%$ 로 분무건조가 낮게 나타났다. 유자즙을 분말화한 연구(22)에서와 같이 분무건 조 분말이 동결건조 분말보다 낮은 수분함량을 나타내었 다.

색도는 분말의 외관상의 품질을 판단하는데 중요한 요인 중 하나로, 색도를 보면 분무건조 분말이 동결건조 분말에 비하여 $\mathrm{L}^{*}$ 값과 $\mathrm{b}^{*}$ 값 및 Hue angle 값은 낮고 $\mathrm{a}^{*}$ 값이 높은

Table 1. Moisture content and color of spray-dride and freezedried powders prepared with Pueraria thunbergiana extracts

\begin{tabular}{cccccc}
\hline \multirow{2}{*}{ Samples } & Moisture & \multicolumn{4}{c}{ Color } \\
\cline { 3 - 6 } & contents $(\%)$ & $\begin{array}{c}\text { Lightness } \\
\left(\mathrm{L}^{*}\right)\end{array}$ & $\begin{array}{c}\text { Redness } \\
\left(\mathrm{a}^{*}\right)\end{array}$ & $\begin{array}{c}\text { Yellowness } \\
\left(\mathrm{b}^{*}\right)\end{array}$ & $\begin{array}{c}\text { Hue angle } \\
(\mathrm{Ho})\end{array}$ \\
\hline Spray-drying & $1.50 \pm 0.14^{\mathrm{b} 1)}$ & $58.54 \pm 0.26^{\mathrm{b}}$ & $4.42 \pm 0.17^{\mathrm{b}}$ & $13.01 \pm 0.18^{\mathrm{a}}$ & $71.30 \pm 0.62^{\mathrm{b}}$ \\
Freeze-drying & $2.92 \pm 0.11^{\mathrm{a}}$ & $66.31 \pm 0.41^{\mathrm{a}}$ & $4.10 \pm 0.04^{\mathrm{a}}$ & $27.44 \pm 0.21^{\mathrm{b}}$ & $81.57 \pm 0.06^{\mathrm{a}}$ \\
\hline${ }^{1}$ Values are mean \pm SD of triplicate determinations. Different superscripts within a column \\
indicate significant differences $(\mathrm{p}<0.05)$.
\end{tabular}

경향을 나타내었다. Jeong 등(23)은 분무건조 탁주 분말이 동결건조 탁주 분말에 비하여 $\mathrm{a}$ *값이 높고 $\mathrm{b}$ *값이 낮았으며 이는 건조 시 온도에 따른 갈변현상으로 보고하였다.

Table 2. Water absorption index (WAI), water solubility index (WSI) and dynamic angle of spray-dried and freeze-dried powders prepared with Pueraria thunbergiana extracts

\begin{tabular}{cccc}
\hline Samples & $\begin{array}{c}\text { Water absorption } \\
\text { index }\end{array}$ & $\begin{array}{c}\text { Water solubility } \\
\text { index }(\%)\end{array}$ & Dynamic angle $\left({ }^{\circ}\right)$ \\
\hline Spray-drying & $0.49 \pm 0.04^{\mathrm{bl})}$ & $94.10 \pm 0.78^{\mathrm{a}}$ & $36.46 \pm 1.86^{\mathrm{a}}$ \\
Freeze-drying & $1.40 \pm 0.01^{\mathrm{a}}$ & $90.69 \pm 4.15^{\mathrm{b}}$ & $33.30 \pm 1.58^{\mathrm{b}}$ \\
\hline
\end{tabular}

${ }^{1)}$ Values are mean \pm SD of triplicate determinations. Different superscripts within a column indicate significant differences $(p<0.05)$.

수분흡수지수(WAI), 수분용해지수(WSI), 안식각

수분흡수지수 및 수분용해지수는 과립, 분말 등 제형가 공의 중요한 품질적 특성이며, 특히 시리얼이나 미숫가루 등 우유나 물 등에 첨가하여 먹는 제품의 경우 분말의 수분 흡수지수나 용해지수는 중요한 가공적성 요인으로 알려져 있다(24). 칡 추출분말의 수분흡수지수(WAI)는 분무건조 가 0.49 0.53, 동결건조가 1.40 1.41로 동결건조가 높게 나 타났다. 또한 수분용해지수(WSI)는 분무건조가 $94.10 \%$, 동 결건조가 $90.69 \%$ 로, 분무건조 분말이 수분흡수지수는 낮 고 용해지수는 높은 것으로 나타났다. 분무건조의 경우 분 말입자가 미세하고 표면적이 넓어 수분흡수가 용이한 반면 건조 시 액체 방울에 수증기 막이 둘러싸여 습구온도로 건조되므로 열내성을 가지고 된다. 분무건조 분말이 동결 건조 분말에 비해 낮은 흡수지수를 나타내는 것은 건조 공정의 특이성에 따른 결과로 판단된다. 분무건조는 다른 건조 방법에 비해 용해성과 유동성이 좋은 구형 분말 제품 을 제조할 수 있으며 연속운전이 가능하여 분말의 물성을 일정하게 유지시킬 수 있으며(25), 향후 적절한 부형제의 사용하여 흡습방지 및 유동성을 높인 제품을 생산할 수 있으므로 분무건조가 동결건조에 비해 산업적 활용이 우수 할 것으로 생각된다.

안식각은 자유낙하한 분말이 바닥에 떨어지면서, 퇴적층 이 차지하는 최대경사의 수평면과 이루는 각도로 안식각이 작을수록 분체의 유동성이 좋은 것으로 판단할 수 있는데, 이를 통해 분말의 caking 정도를 간접적으로 측정할 수 있다 (26). 분무건조 분말의 안식각은 $36.46^{\circ}$ 였으며, 동결건조 분말은 $33.30^{\circ}$ 로 동결건조 분말의 안식각이 낮게 나타났다. Peleg 등(27)에 따르면, 안식각의 크기가 $35^{\circ}$ 까지는 자유로 운 유동능력을 나타내고, 35 45에서는 약간 응집력이 있 는 분체이며 $45 \sim 55^{\circ}$ 는 응집력이 있는 분체로 유동성이 약 간 감소되고 $55^{\circ}$ 이상일 때는 매우 응집력이 강한 분체로 유동 능력이 한계적 상태를 말한다. 따라서 동결건조 분말 은 분무건조 분말에 비하여 유동능력이 자유로우며 분무건 조 분말의 경우 동결건조 분말에 비해 약간의 응집력 및 
흐름성을 가져 분체 식품에 적용 시 적절할 것으로 사료된 다.

\section{총 폴리페놀 및 총 플라보노이드 함량}

건조방법에 따른 칡 분말의 총 폴리페놀 및 플라보노이 드 함량을 조사한 결과는 Table 3과 같다. 총 폴리페놀 함량 은 분무건조와 동결건조에서 $\mathrm{g}$ 당 각각 $18.09 \mathrm{mg}$ 과 12.65 $\mathrm{mg}$ 으로 분무건조가 동결건조에 비하여 유의적으로 높은 함량을 나타내었다. 총 플라보노이드 함량에서는 분무건조 와 동결건조가 각각 $13.42 \mathrm{mg}$ 과 $8.08 \mathrm{mg}$ 로 분무건조가 동결 건조에 비하여 유의적으로 높은 함량을 나타내었다. 식품 에 열이 가해지면 아미노산의 peptide, 단백질의 a-amino group과 당의 반응에 의한 비효소적 갈변반응이 일어나게 되며 적절한 열처리는 식품 성분 중 환원당과 질소화합물의 갈색화 반응을 일으키며 생성된 물질은 항산화 효과를 가진 다고 알려져 있다(28). 따라서 분무건조가 동결건조에 비하 여 유의적으로 높은 함량을 나타내는 것은 분무건조 시 열에 의한 갈변화 반응으로 사료된다. 한편, $\mathrm{Oh}$ 등(29)은 칡뿌리 중의 항산화 성분을 획분한 결과 항산화성분은 flavonoide 성분의 일종인 puerarin으로 확인 동정되었으며, 그 외의 성분으로는 daidzin 및 daidzein 등이 검출되어 칡뿌 리의 주요한 폴리페놀 물질은 puerarin이라 보고하였다.

Table 3. Total polyphenol and flavonoid contents of spray-dried and freeze-dried powders prepared with Pueraria thunbergiana extracts

\begin{tabular}{ccc} 
& & $(\mathrm{mg} / \mathrm{mL}$, dry basis $)$ \\
\hline Samples & Polyphenols $\left(\mathrm{mgGAE}^{\mathrm{l}} / \mathrm{g}\right)$ & Flavonoids $\left(\mathrm{mgRE}^{2} / \mathrm{g}\right)$ \\
\hline Spray-drying & $18.09 \pm 1.12^{\mathrm{b} 3)}$ & $13.42 \pm 0.07^{\mathrm{a}}$ \\
Freeze-drying & $12.65 \pm 1.53^{\mathrm{a}}$ & $8.08 \pm 0.06^{\mathrm{b}}$ \\
\hline
\end{tabular}

${ }^{1)} \mathrm{GAE}$, gallic acid equivalents.

${ }^{2)} \mathrm{RHE}$, rutin hydrate equivalents.

${ }^{3)}$ Values are mean $\pm \mathrm{SD}$ of triplicate determinations. Different superscripts within a column indicate significant differences $(\mathrm{p}<0.05)$.

\section{$\mathrm{DPPH}$ 및 $\mathrm{ABTS}$ radical 소거활성}

칡 추출물의 분무건조 및 동결건조한 분말의 $\mathrm{DPPH}$ 및 ABTS radical 소거활성을 조사한 결과는 Fig. 1, 2와 같다. $\mathrm{DPPH}$ 소거활성의 경우 모든 농도에서 분무건조 분말이 동결건조 분말에 비해 높은 활성을 나타내었으며, 특히 5 $\mathrm{mg} / \mathrm{mL}$ 농도에서 분무건조가 $85.38 \%$, 동결건조가 $59.38 \%$ 로 분무건조가 동결건조에 비해 더 높은 $\mathrm{DPPH}$ 소거활성을 나타내었다. $\operatorname{Kam}(30)$ 의 연구에 따르면 칡 추출물의 농도가 높아질수록 free radical도 증가하는 경향이 나타났으며, 플 라보노이드 농도가 진할수록 free radical 제거효과가 상승 한다고 보고하여 본 연구 결과와 일치하는 경향을 나타내었 다. 칡 추출물의 분무건조 및 동결건조한 분말의 ABTS radical 소거활성을 조사한 결과 Fig 2와 같다. 전체적으로 분무건조 분말이 $0.05 ~ 0.5 \mathrm{mg} / \mathrm{mL}$ 농도에서 동결건조보다 높은 ABTS radical 소거활성을 보였으며 높은 활성을 나타 내었다. DPPH 및 $\mathrm{ABTS}$ 라디칼 소거활성 측정 결과 분무건 조를 실시한 칡추출 분말이 동결건조한 칡추출 분말보다 모든 농도에서 높은 활성을 나타냄을 알 수 있었다. 분무건 조 시 항산화 활성이 증대되는 현상은 칡 추출물에 존재하 는 환원성 물질, 고분자 물질, 라디칼 소거활성을 가지는 물질 등으로 인해 폴리페놀의 함량이 증가함에 따라 활성 또한 증가한 것으로 판단된다. 또한 분무건조는 동결건조 와 달리 $130 \sim 300^{\circ} \mathrm{C}$ 의 온도를 이용하여 건조는 방법으로 식품 내에 열을 가하게 되면서 가지고 있는 아미노산, 단백 질 당 물질 등의 갈색화 반응으로 항산화 효과를 가지게 되며 이는 폴리페놀 및 플라보노이드의 결과와 유사한 경향 을 나타내었다.

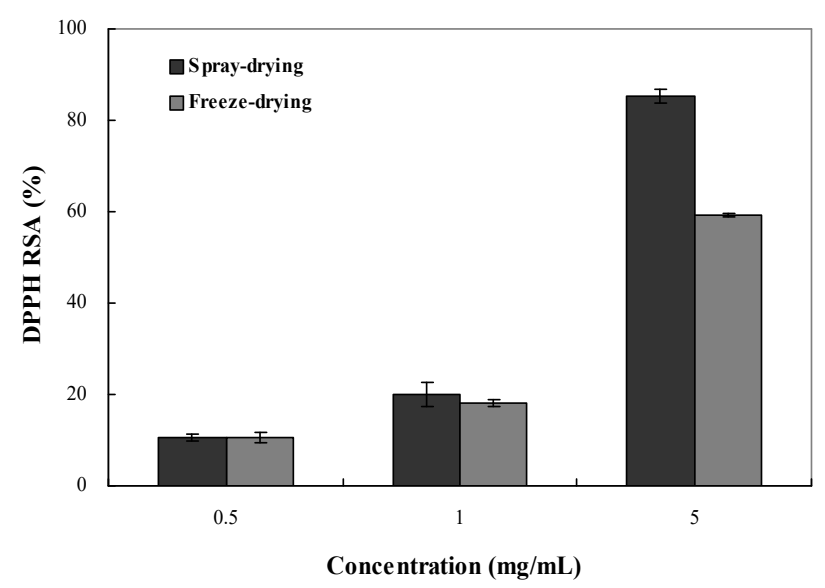

Fig. 1. Electron donating ability of spray-dried and freeze-dried powders prepared with Pueraria thunbergiana extracts. Values are means \pm standard deviation of triplicate determinations.

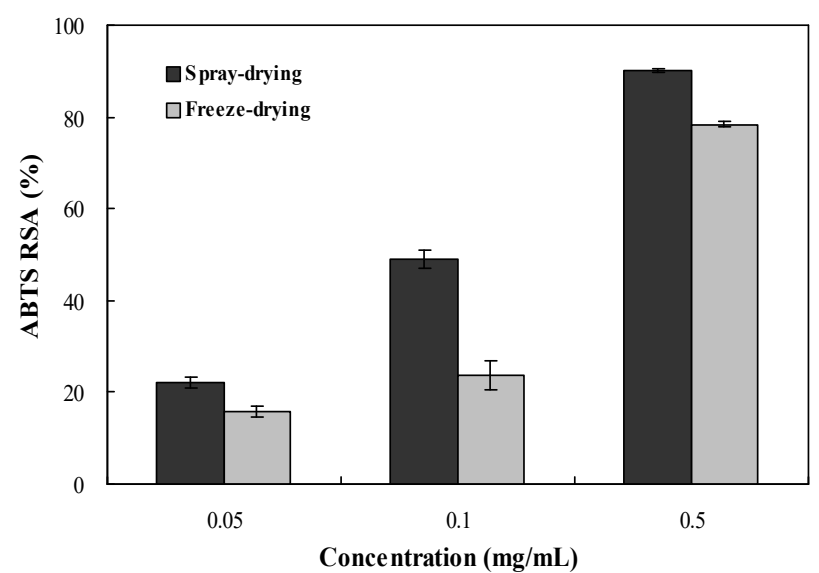

Fig. 2. ABTS radical scavenging ability of spray-dried and freeze-dried powders prepared with Pueraria thunbergiana extracts. Values are means \pm standard deviation of triplicate determinations. 


\section{요 약}

칡의 활용성 증대 및 식품 소재로 개발하기 위하여 칡을 열수추출 한 후 추출물을 분무 및 동결건조를 실시하여 칡 추출분말의 품질특성을 조사하였다. 건조방법을 달리한 칡 추출분말의 색도는 분무건조 분말에서 명도와 황색도는 낮고 적색도는 높았다. 수분흡수지수는 동결건조 분말이 1.40 1.41로 분무건조에 비해 높았고, 수분용해지수는 분 무건조가 $94.10 \%$ 로 높았으나 안식각을 측정한 결과 분무건 조 분말이 동결건조 분말에 비해 응집력 및 흐름성을 가지 는 것을 확인하였다. 한편, 칡 추출분말의 총 폴리페놀 및 플라보노이드 함량은 분무건조가 각각 $18.09 \mathrm{mg} / \mathrm{g}, 13.42$ $\mathrm{mg} / \mathrm{g}$ 으로 동결건조 보다 높은 함량을 나타내었으며, DPPH 및 $\mathrm{ABTS}$ 라디칼 소거활성에서는 전체적으로 농도 의존적 으로 증가하는 경향을 나타내었으며 모든 농도에서 분무건 조 분말의 라디칼 소거활성이 높았고 특히 $\mathrm{DPPH}$ 라디칼 소거활성 경우 분무건조가 $85.38 \%$, 동결건조가 $59.38 \%$ 로 분무건조 분말이 높은 소거활성을 보였다. 이러한 결과를 종합해 볼 때, 칡 추출분말 제조 시 분무건조 분말이 동결건 조 분말에 비하여 가공적성 및 항산화 활성이 우수하여 가공 산업의 활용도가 높을 것으로 판단된다.

\section{References}

1. Rho SJ (2012) Physiological effects and quality characteristics of bread and cake products with arrowroot powder. Ph D Thesis, Sejong University, Korea, p 11

2. Suzuki A, Hizukuri S, Takeda Y (1981) Physicochemical studies and kuzu starch. Cereal Chem, 58, 286-290

3. Choo MK, Park EK, Yoon HK, Kim DH (2002) Antithrombotic and antiallergic activities of daidzein, a metabolite of puerarin and daidzin produced by human intestinal microflora. Biol Pharm Bull, 25, 1328-1332

4. Seok JS, Kim DH (2003) Microencapsulation of isoflavone derived from Pueraria. J Korean Dairy Technol Sci, 21, 105-113

5. Zheng G, Zahng X, Meng Q, Gong W, Wen X, Xie $\mathrm{H}$ (2002) Protective effect of total isoflavone from Pueraria lobata on secondary osteoporosis induced by dexamethasone in rats. Zhongyaocai, 25, 643-646

6. Lee SW, Kim HW, Han SH, Rhee C (2009) Effect of heat treatment conditions on the characteristics of gel made from arrowroot starch in Korea cultivars. Korean J Food Nutr, 22, 387-395

7. Kim JJ, Lee HJ, Yee ST (2012) Effect of Pueraria thunbergiana extracts on the activation of lmmune cells.
J Life Sci, 22, 1107-1113

8. Lee YS, Lim NY, Lee KH (2000) A study on the preparation and evaluation of dried noodle products made from composite flours utilizing arrowroot starch. Korean J Soc Food Sci, 16, 681-688

9. Gu SY, Lee HG (2001) The sensory and textural characteristics of Chicksulgi. Korean J Food Cookery Sci, 17, 523-532

10. Lee JS (2012) Quality characteristics of arrow root starch Mook added with Schizonepetae Spica. MS Thesis, Myongji University, Korea

11. Hwang EH, Kim KH (2008) A study on the quality of Ramyon made from Korean wheat and arrowroot (Pueraria thunbergiana B) starch. KJHE, 17, 151-158

12. Han GS, Hwang SY, Rho SJ (2013) Quality characteristics of white bread with arrowroot powder. J East Asian Soc Dietary Life, 23, 778-788

13. Kim JW, Kwon YR, Youn KS (2012) Quality characteristics and antioxidant properties in spray-dried and freeze-dried powder prepared with powdered seaweed extracts. Korean J Food Sci Technol, 44, 716-721

14. Lee NJ, Lee SJ (2009) Physical properties of freeze-dried powder of Aloe Vera gel with respect to the concentrating degree as pre-treatment. Korean J Food Sci Technol, 41, 32-36

15. Mok CY (2005) Quality improvement of spray-dried Omija (Schizandra chinensis Baillon) tea powder by roasting of Omija and by adding of grape juice. Food Eng Prog, 9, 125-132

16. Phillips RD, Chinnan MS, Branch AL, Miller J, Mcwatters KH (1998) Effects of pre-treatment on functional and nutritional properties of cowpea meal. J Food Sci, 53, 805-809

17. Walstra P, Geur TJ, Noomen A, Jellema A, Van Boekel MSJS (1999) Dairy technology - Principles of milk properties and processes. Marcel Dekker Inc, USA, New York, p 455-457

18. Dewanto V, Wu X, Adom KK, Liu RH (2002) Thermal processing enhances the nutritional value of tomatoes by increasing total antioxidant activity. J Agric Food Chem, 50, 3010-3014

19. Abdel-Hameed ESS (2009) Total phenolic contents and free radical scavenging activity of certain Egyptian Ficus species leaf samples. Food Chem, 114, 1271-1277

20. Blois MS (1958) Antioxidant determination by the use of a stable free radical. Nature, 181, 1199-1200 
21. Re R, Pellegrini N, Proteggente A, Pannala A, Yang M, Rice-Evans C (1999) Antioxidant activity applying an improved ABTS radical cation decolorization assay. Free Radic Biol Med, 26, 1231-1237

22. Nam HW, Hyun YH (2003) Drying of citron juice from by-product of citron tea manufacturing. Korean J Food Nutr, 16, 334-339

23. Jeong JW, Park KJ, Kim MH, Kim DS (2006) Changes in quality of spray-dried and freeze-dried Takju powder during storage. Korean J Food Sci Technol, 38, 513-520

24. Lee YR, Choi YH, Koh HJ, Kang MY (2001) Quality characteristics of brown rice flakes prepared with giant embryonic rice and normal rice cultivars. Korean J Food Sci Technol, 33, 540-544

25. Kim DM, Kwak HS (2004) Nanofood materials and approachable development of nanofunctional dairy products. J Korean Dairy Technol Sci, 22, 1-12
26. Bae SJ (2010) Effects on manufacturing of persimmon powders by treatment of sulfite and maltodextrin. MS Thesis, Chonnam National University, Korea, p 51

27. Peleg M, Mannheim CH, Passy N (1973) Flow properties of some food powders. J Food Sci, 38 959-964

28. Kim JH, Kwak DY, Choi MS, Moon KD (1999) Comparison of the chemical compositions of Korean and Chinese safflower (Carthamus tinctororius L.) seed. Korean J Food Sci Technol, 31, 912-918

29. Oh MJ, Lee KS, Son HY, Kim SY (1990) Antioxidative components of pueraria root. Korean J Food Sci Technol, 22, 793-798

30. Kam KS (2007) Antioxidative activity and its application of pueraria thunbergiana extracts. MS Thesis, Soongsill University, Korea, p 30-31 